\title{
Asset Liability Mismatch- An Empirical study on nationalized commercial banks in Bangladesh
}

\author{
Umme Hanna Airin Ara ${ }^{1}$, E Eliza Haque ${ }^{2}$ \\ ${ }^{1}$ Assistant Professor, Department of Business Administration, Stamford University Bangladesh, BANGLADESH \\ ${ }^{2}$ Assistant Professor, Department of Business Administration, United International University, BANGLADESH
}

\begin{abstract}
Liquidity Management is the integral part of monetary management. Liquidity management, ensuring sustainable solvency are the two core prerequisites for smooth functioning of banks in the long run. The balancing act between a bank's own liquidity and its role as a liquidity creator, especially in times of financial distress or crisis, is the focus of this paper. The data collected mostly from the annual reports of the selected banks. Liquidity has been analysed by using gap analysis. The CV (Coefficient of variation) has been used to analyse the volatility of liquidity in the selected gap. The analysis showed that Sonali Bank suffered highest negative liquidity gap among the banks. Bat the gap was highly volatile in case of Agrani bank Ltd. On the other hand there is a statically significant difference among the banks in terms of variation in Liquidity.
\end{abstract}

Key Words: Liquidity Management, Gap, CV, ANOVA

\section{INTRODUCTION}

$\mathrm{L}$ Liquidity management is an important aspect of monetary policy implementation, while the other integral component of monetary policy, i.e. economic management, involves promoting sustainable economic growth over the long term by keeping monetary and credit expansion in step with an economy's noninflationary output potential, liquidity or reserve management as a shorter time horizon. In order to maintain relative macro-economic stability, reliance is placed on liquidity management to even out the swings in liquidity growth in the banking system.

Solvency and liquidity are the two core pillars of banking. Solvency risks arise from the credit creation and investment function in banking, as some obligors may default and some investments may lose their value, resulting in unexpected losses. Liquidity risks arise from the maturity transformation function in banking specifically, banks borrow at a short duration from depositors or markets, and lend at a long duration to borrowers or invest in illiquid securities. In most banks, solvency and liquidity are managed as separate functions with minimal consideration for interdependencies. Risk management is usually responsible for solvency, mostly expressed in the language of the Basel framework, whereas treasury and asset-and-liability management departments are responsible for funding and liquidity.

Financial inter-mediation role of the commercial banks hence becomes the bed-rock of the two major functions of commercial banks namely deposit mobilization and credit extension. An adequate financial intermediation requires the purposeful attention of the bank management to profitability and liquidity, which are two conflicting goals of the commercial banks. These goals are parallel in the sense that an attempt for a bank to achieve higher profitability will certainly erode its liquidity and solvency positions and vice versa.

Any commercial bank, conventional or Islamic, is required to monitor and manage its liquidity position effectively and cautiously. In this study, we will try to focus on how the state owned banks are managing their liquidity position in Bangladesh. The importance of liquidity transcends the individual bank since a liquidity shortfall at a single organization can have systemic repercussions. The management of liquidity is therefore among the most important activities conducted at banks. Over time, there has been a declining ability to rely on core deposits and an increased reliance on wholesale funding. Recent technological and financial innovations have provided banks with new ways of funding their activities and managing their liquidity, but recent turmoil in global financial markets has posed new challenges for liquidity management.

The term liquidity is often used in multiple contexts. An asset's liquidity can be used to describe how quickly, easily and costly it is to convert that asset into cash (Berger \& Bouwman, 2008). Liquidity can also be used to describe a company by the amount of cash or near cash assets a company has; the more liquid assets, the higher a company's liquidity. Financial ratios that measure 
liquidity are referred to as a company's liquidity ratios. One such ratio is the current ratio which determines a company's ability to pay short term debts as they come due (Van Ness, 2009). Liquidity risk has many definitions but the one that can be derived from the ratio is the probability that a company will not be able to pay its short term obligations as they come due. This inability can lead a company to face serious financial problems. In addition to this, liquidity risk can also be defined in terms of the counterparty to a transaction. In this sense the term means the risk inherent in the fact that the counterparty may not be able to pay or settle the transaction even if they are in good financial standing, because of a lack of liquidity (Petria \& Petria, 2009).

Aside from managing their own liquidity, banks play another role with regards to liquidity by creating liquidity for the market. Due to the growth of the commercial paper, equity, and bonds markets in recent decades, the role of banks as the sole provider of capital to large companies has diminished. This results from companies looking for the type of financing that best suits their specific needs. Banks still play a largely influential role in financing. They are a primary issuer of capital to companies who seek loans to fulfill a portion of their financing needs. Many times they act as the fallback crutch on which companies support themselves in times of difficult financing. Companies can do so by establishing credit lines with banks to secure funding that ensures liquidity when it is needed most. In summary, banks face two central issues regarding liquidity. Banks are responsible for managing liquidity creation and liquidity risk. Liquidity creation helps depositors and companies stay liquid, for companies especially when other forms of financing become difficult. Managing liquidity risk is to ensure the bank's own liquidity so that the bank can continue to serve its function. This balancing act between a bank's own liquidity and its role as a liquidity creator, especially in times of financial distress or crisis, is the focus of this paper. There has been a great deal of scrutiny on this issue due to the financial crisis that began in 2007 and is still affecting the economy today. This paper compares and contrasts several of the ideas and theories presented in academic literature.

\section{THEORETICAL REVIEW}

The main technique used to measure liquidity position is liquidity gap analysis. Liquidity gaps are differences between assets and liabilities at present time and in the future (Thomas Barnes 15 Jan 2010). Gaps generate liquidity risk; deficits will require funding and excess will result in interest rate risk. Gaps can either be static or dynamic. Static gaps will consider all assets and liabilities which are actually present in the balance sheet. In such case the analysis shows a reduction of the assets and liabilities as they mature. Dynamic gaps are simply the consideration of actual plus projected inflows and outflows; these depend on business uncertainties (Hampel et al 1999). A liquidity gap schedule provides an analytical framework for measuring future funding needs by comparing the amount of assets and liabilities maturing over specific time intervals (Thomas Barnes 15 Jan 2010).

Most financial firms such as insurance companies use various metrics to control their liquidity risk. This consists of three basic approaches which can be categorized as: the liquid assets approach, the cash flow approach, and a combination of both. (Sharma paul et al 2006)

Under the liquid assets approach, the company needs to maintain liquid instruments on their balance sheet which can be consulted whenever required. (Ratios are the relevant metrics in this approach). Under the cash flow matching approach, the company tries to match cash outflows against contractual cash inflows across a range of near-term maturity buckets. This approach is mostly used by insurance companies.

The mixed approach is a combination of both cash flow approach and the liquid assets approach. The company attempts to match cash outflows each time bucket against a combination of contractual cash inflows. Insurance companies place more emphasis on the cash flow matching approach. When gaps in maturity buckets are unfavorable, insurance companies would utilize the mixed approach to help ensure that they will be able to meet their obligations to provide cash to counterparties. (Sharma et al 2006)

\section{Ratio Analysis}

Ratio analysis involves comparisons because company ratios are compared with those of other firms in the same industry, that's the industry average figures. Also, managers usually go a step further and compare their ratios with those of smaller set of leading companies in their industry.

This technique is called benchmarking. With benchmark ratio are calculated for each company and they are listed in descending order. (Foster, 1986)

Limitations of Ratio Analysis

1) Different accounting and operating practices of the commercial banks can distort comparisons. For example, inventory valuation and depreciation methods can affect financial statements thus, distort comparisons among commercial banks.

2) It is difficult to generalize about whether or not a particular ratio is good. For example, a high current ratio may indicate a strong liquidity position, which is good or excessive cash that is bad because excess cash in the bank is a non-earning asset.

3) Inflation may have badly distorted the company's balance sheet, that is, recorded values are often substantially different from true values. Therefore, depreciation charges, inventory costs and profits may also affected.

4) When uni-variate analysis technique is used, some ratios may look good while others may look bad making difficult to judge whether the company is performing good or bad. 
5) The decision on cut-off point is somehow difficult to make in order to make decision.

6) Commercial banks also employ window dressing techniques to make their financial statements look better than they really are so as to attract interested parties such as investors and Financial Institutions.

7) Those ratios targeted to compare performance against the industrial standard may not be effective because the industrial standard may not exit.

\section{Financial Performance}

Performance evaluation entails the analysis of the level of financial and economic performance using both the qualitative and the quantitative data. In this case there are two possible ways of analysis that is basically quantitative in nature and qualitative in nature On the case of qualitative they can't be quantified but they basically influence the performance of the entities (Shapiro, 1991). Financial performance can easily be calculated by looking the components of the financial statements which are the income statements, balance sheet and the statement of equity changes (ACCA, 2007).These components help to depict the true picture of the business by relating the items of the components of the financial statements. A comparison of ratios of the same firm over time is important in evaluating changes and trends in the firm's financial condition including profitability. This comparison may be judged with those of similar firms in the same line of business and when appropriate with an industrial average's (Horne, 2000).

\section{Financial Statement Analysis}

This seeks on establishing the relationships with the set of financial statements at a point in time with trends in these relationships over time (Baisi 2005). Financial statements analysis involves the analysis and interpretations of financial statements in order to identify the strength and weakness of the company. The financial statements analysis is the process of establishing the relationship between various items of balance sheet and income statements. Financial statement analysis is a part of a larger information processing system on which informed decisions can be based upon (Varn Horne, 2000). The evaluation of financial statements takes the historical

information for the number of years. The evaluation can be of trend analysis or cross sectional analysis. Normally the historical financial statements provide the reliable source of information for predicting the future performance of the business. In making financial statements analysis various parties need to be satisfied existing and potential stakeholders, employees, suppliers, competitors, governments, and the public at large. The needs of the above group are different and each group has its own set of need e.g. management need financial statement for profit maximization but the shareholders need financial statements for wealth maximizations and overall prospect of the company (Bais, 2005).

\section{Liquidity Position Analysis}

This refers to the ability of commercial banks to pay its obligations as it falls due and the level of funding. It includes core deposits to total deposits; this ratio is calculated by summing of all core deposits divided by total deposit, it measures the volatility of deposits. Liquid assets to demand liabilities this is calculated by taking the sum of all assets maturing within one year divided by all liabilities with the same maturity period. This intends to capture the liquidity mismatch of assets and liabilities and provides an indication of the extent to which banks could meet short term withdrawal of funds without facing liquidity problems. Gross loans to total deposits this is calculated by taking gross loans divided by total deposits, measure the extent to which deposits have financed loan portfolio which are considered illiquid assets (BOT, 2007). In commercial banks liquidity refers to the reserve of cash, securities, a bank ability to convert an asset into cash, and unused bank lines of credit, the faster the conversion the more the liquid is the asset. Liquidity must be sufficient to meet all maturing unsecured debt obligations due within a one year time horizon without incremental access to the unsecured market, probably the most critical issue to examine for the bank ability to meet obligation. If the earning is poor and liquidity is high the bank lending may be conservative with high proportions of proceeds from deposits are invested in low yielding assets. If earnings are aggressive lending policy coupled with heavy borrowing. The key ratios are; loans as a percentage of deposits that is loan to total deposits, liquid asset to total deposit and loan loss or non-performing loans to total loan (Vinolas, 2003).

Liquidity and funding, funding is what a bank relies upon to grow its business, it is provided by deposits, short-term debt and longer term debt, funding it means access to capital. Liquidity is what a bank requires if funding is interrupted and the bank must still to maintain its obligation, the bank deposit rate indicate how the bank is financing the balance sheet.

\section{LITERATURE REVIEW}

In this case there are substantial researches which have been made with regard to bank liquidity, among of them are: Vodava (2011) made analysis of liquidity of Czech commercial banks and its determinant, his results showed that there is a positive link between liquidity and capital adequacy. Shin (2007) indicated that in turbulent economic sphere liquidity position is very important as any changes will bring the changes in the network of the banks. Nikolaon et al (2009) in their paper funding liquidity risk definition and measurements pointed that funding for liquidity are stable and sometimes low in turmoil period, therefore liquidity management is necessary. Basel committee (2009) indicated that the liquidity level of the commercial banks is the paramount importance for the sustainability of the banks and they further indicated that the entire inner role of the bank is to ensure the stability of the cash flow. 
Barua (2001) in his paper liquidity scenario in commercial banks of Bangladesh, the results showed that liquidity level has been dropped by $2 \%$ due to excess government borrowing and inconsistent growth of deposit. This has been supported by the liquidity ratio.

Jahangir, Shill and Haque (2007) stated that the traditional measure of profitability through stockholder's equity is quite different in banking industry from any other sector of business, where loan-to-deposit ratio works as a very good indicator of banks' profitability as it depicts the status of asset-liability management of banks. But banks' risk is not only associated with this asset liability management but also related to growth opportunity. Smooth growth ensures higher future returns to holders and there lies the profitability which means not only current profits but future returns as well. So, market size and market concentration index along with return to equity and loan-to-deposit ratio grab the attention of analyzing the banks' profitability.

According to Al-Shamrnari and Salirni (1998) profitability ratio especially return on equity (ROE) signals the earning capability of the organization. They also suggest that higher return on equity (ROE) ratio is appreciable as it is the primary indicator of bank's profitability and functional efficiency.

According to the Deloiite (the second largest accountancy firm in the world) report of Middle East Islamic Financial Survey done on September 25, 2010 liquidity ratio received the highest score and was considered the top priority, followed by the solvency ratio, leverage ratio and return on average assets, respectively. The issue of liquidity in Islamic finance has been widely argued, and several proposals are now under consideration to develop this segment of the industry. Central banks in the region and elsewhere in Asia, as well as industry standardsetters, are setting the stage for developing this market by means of innovative Shariah-compliant short- and medium-term instruments.

Liquidity in financial market has numerous implications. Liquidity signifies the ability of a financial firm to keep up all the time a balance between the financial inflows and outflows over the time. (A \& Ganga, 2009).

The liquidity ratios Net loans to total asset ratio, liquid asset to deposit ratio, short term fund ratio is used for comparison of Islamic and conventional banks of Pakistan for the period 2006-2010. The financial ratios and trend analysis reveals a good performance of Islamic bank. (Akhter, Raza, Orangzab, \& Akram, 2011).

According to Barua (2001) the excess reserve held with the central bank, liquidity positions of commercial banks can also be reviewed through some indicator ratios viz. liquid assets as a percentage of total assets and growth rate of advance \& deposits. Liquid assets as a percentage of total assets of commercial banks can provide a very good indication of liquidity position. Optimal liquidity position is essential for smooth operation of banking system as well as the economic development of the country. Excess liquidity hampers the profitability of banks and liquidity shortage hinders the growth of private sector.

Muzahidul \& Hasibul (2009) considered both short-term and long-term liquidity positions in their study. However, maturity-wise liquidity situation has also been observed. To estimate the liquidity situation maturity-wise and total liquidity gap have been calculated. Furthermore, the study also tried to examine whether key performance indicators of these banks had any influence on liquidity position during the period under study and found that the KPIs like EPS, P/E ratio, ROE, ROA had influential role in determining the extent of liquidity.

Another interesting study examines not what banks do during a crises involving liquidity management but what banks have done before such crises. By studying five crises, three market crises and two banking crises, research suggests that there was either too much or too little liquidity creation before all of these crises. However, this idea remained non-conclusive (Berger \& Bouwman, 2008). What was most interesting was the data surrounding the current economic crisis. Prior to and during the first portion of the current crisis, the data shows an abnormally high build-up of liquidity creation by banks. Berger and Bouwman refer to this as the "dark side" of liquidity. The idea states that banks may have created too much liquidity in the market and this is what led to such lax lending standards, too much available credit and too many credit lines. This idea is somewhat contradictory to the assumption that too little liquidity causes financial vulnerability and instead posits that too much liquidity can also cause financial vulnerability.

There are many factors that affect banks own liquidity and in turn affect the amount of liquidity they can create. These factors have a varying degree of influence on the balance between liquidity risk and liquidity creation, or a bank's liquidity management. A bank's assets and liabilities play a central role in their balancing of liquidity risk and creation. A bank's liabilities include all the banks sources of funds. Banks have three main sources of funds: deposit accounts, borrowed funds, and long term funds. The amounts and sources of funds clearly affect how much liquidity risk a bank has and how much liquidity it can create. The easier a bank can access funds the less risk it has and the higher amount of funds it holds the more liquidity it can create, if willing to do so. Deposit accounts are made up of transaction deposits, also known as demand deposits, savings deposits, time deposits, and money market deposit accounts. The borrowed funds of a bank come from loans from other banks via the Federal Funds market, loans from the Federal Reserve Bank, repurchase agreements, and Eurodollar borrowings. The longer term sources of funds for banks are bonds that banks issue and bank capital (Madura, 2007). 
One group of researchers studied liquidity management by focusing on the liability side of the balance sheet analyzing demand deposit accounts and the amount of undrawn credit lines a bank had. These two liabilities are major factors of a bank's liquidity risk. Demand deposit accounts give banks a larger cash base and thus are a form of liquidity. Undrawn credit lines are a liquidity risk that is off the balance sheet; companies with established credit lines can borrow from banks when they need it and thus decrease a bank's liquidity. These two opposing liquidity factors can be analyzed in times of financial distress, for example by looking at the Russian default of 1998 and its after affects. Studies indicate that banks balance their liquidity risk and their role as a liquidity creator by balancing their demand deposit accounts and their amount of undrawn credit lines; banks that did so fared better financially (Gatev, Schuermann, \& Strahan, 2007).

\section{Data AND Methodology}

Data are sourced from "liquidity statement" as reported in Annual Reports of years from 2007 to 2011 of four nationalized commercial banks operating in Bangladesh namely Sonali Bank Ltd, Rupali Bank Ltd, Janata Bank Ltd. and Agrani Bank Ltd. As per the information presented in annual reports " net liquidity gap" is computed as asset over liability of following five different maturity segments-

- $\quad$ Upto 1 month maturity

- 1-3 months maturity

- 3-12 months maturity

- 1-5 years maturity

- More than 5 years maturity

The study is an attempt to disclose the liquidity condition concentrating on individual and comparative analysis of net liquidity gap. Where, a negative gap in a particular segment implies incapability to meet liabilities with assets of that maturity. On the other hand, positive liquidity gap indicates assets can meet liabilities when they become mature. Although a very high positive gap leaves the bank with a large amount of idle assets that may eventually cut profitability.

To make the comparison clear the year wise growth rate of net liquidity gap during the time period is also calculated. For present the summarize information of net short term and net long term gap the first three (below 1 year) time segments are aggregated under short term head and rest two "more than 1 year" buckets are summed up for having long term net liquidity gap.

To evaluate comparative volatility of net gap among all the concerned banks, CV (coefficient of variation) is measured for each time bucket. Moreover to know whether the net liquidity gap of different banks are significantly different at various time bucket, "Analysis of Variance" is performed.

\section{ANALYSIS AND FINDINGS}

The present article concentrates on exploring the liquidity condition of the nationalized commercial banks (NCBs) in Bangladesh and if any significant differences is there. For that at first the individual performance of each bank is evaluated according to 5 maturity bucket. Then comparative analyses of four NCBs are performed focusing on the differences in net liquidity gap of each time bucket.

Analysis of Liquidity Condition of Sonali Bank Ltd.:

The evaluation of net liquidity gap over the period of 2007 to 2011 reveals a good condition in maintaining higher level of assets than liabilities in total and high growth rate for the period ( Table: 1) but somewhat a critical condition in short term maturity buckets (Table: 2) which indicates poor liquid asset management of the bank. Although the negative net liquidity gap in short term time brackets decreased gradually from 2007 to 2010 but in 2011, it rose to a high extent. Another implication of negative gap in aggregate short term time bucket and positive gap of long term bucket as information revealed by table- 2 may be the indication of using short term liabilities to finance long term assets.

Table1: net liquidity gap of Sonali Bank

\begin{tabular}{|c|c|c|c|c|c|}
\hline Maturity Bucket & 2007 & 2008 & 2009 & 2010 & 2011 \\
\hline & net liquidity gap & net liquidity gap & net liquidity gap & net liquidity gap & net liquidity gap \\
\hline upto 1 month & $-53,490,834,831$ & $-44,646,908,973$ & $-17,192,863,329$ & $-1.03667 \mathrm{E}+11$ & $-81,532,482,743$ \\
\hline 1-3 month & $-5,292,549,379$ & $1,067,882,548$ & $15,932,518,156$ & -5632813672 & $-38,884,531,106$ \\
\hline $3-12$ months & $-43,519,041,221$ & -18139235172 & $-44,681,391,894$ & -2387479916 & $78,484,230,431$ \\
\hline $1-5$ years & $47,784,027,931$ & 53594837775 & $30,939,117,063$ & 11026796779 & $-69,477,585,534$ \\
\hline more than 5 years & $76,260,126,399$ & 32541137959 & $45,477,978,117$ & $1.46434 \mathrm{E}+11$ & $167,502,671,856$ \\
\hline Total & $21,741,728,899$ & $24,417,714,137$ & $30,475,358,113$ & $45,773,859,298$ & $56,092,302,905$ \\
\hline Growth Rate & & 12.30806092 & 24.80839911 & 50.19957806 & 22.542219 \\
\hline
\end{tabular}


Asian Business Review, Volume 4, Number 2/2014 (Issue 8)

ISSN 2304-2613 (Print); ISSN 2305-8730 (Online)

Table 2: Aggregated short term and long term net liquidity gap of Sonali Bank

\begin{tabular}{|l|l|l|l|}
\hline Year & $\begin{array}{l}\text { Short Term } \\
\text { Liquidity Gap }\end{array}$ & $\begin{array}{l}\text { Long Term } \\
\text { Liquidity Gap }\end{array}$ & $\begin{array}{l}\text { Total Liquidity } \\
\text { Gap }\end{array}$ \\
\hline 2007 & $-102,302,425,431$ & $124,044,154,330$ & $21,741,728,899$ \\
\hline 2,008 & $-61,718,261,597$ & $86,135,975,734$ & $24,417,714,137$ \\
\hline 2,009 & $-45,941,737,067$ & $76,417,095,180$ & $30,475,358,113$ \\
\hline 2,010 & $-1.11687 \mathrm{E}+11$ & $1.57461 \mathrm{E}+11$ & 45773859297 \\
\hline 2,011 & $-41,932,783,418$ & $98,025,086,322$ & $56,092,302,904$ \\
\hline
\end{tabular}

Analysis of Liquidity Condition of Rupali Bank Ltd:

Table :3 presents the asset liability mismatch from the year 2007 to 2011 along with yearly growth rate. The presented information shows that Rupali Bank's inefficiency in managing short term as well long term assets and liabilities. However the condition seems to be improving from 2010 to 2011, although the growth rate is very low. The condition is more vivid in table : 4 as it presents information summarizing all the short term buckets as "short term liquidity gap" and then summarizing two long term buckets under the head of " long term liquidity gap", side by side.

Table 3: Net liquidity gap of Rupali Bank Ltd.

\begin{tabular}{|l|l|l|l|l|l|}
\hline Maturity Bucket & $\mathbf{2 0 0 7}$ & $\mathbf{2 0 0 8}$ & $\mathbf{2 0 0 9}$ & $\mathbf{2 0 1 0}$ & $\mathbf{2 0 1 1}$ \\
\hline & net liquidity gap & net liquidity gap & net liquidity gap & net liquidity gap & net liquidity gap \\
\hline upto 1 month & $-7,815,148,863$ & 8643506816 & $192,633,617$ & 536720869 & $313,753,969$ \\
\hline $1-3$ month & $-7,156,132,276$ & -8539302045 & $1,093,172,338$ & 1566161875 & $667,980,802$ \\
\hline 3-12 months & $3,772,699,212$ & -6275170795 & $5,394,110,617$ & 3534038311 & $463,660,750$ \\
\hline $1-5$ years & $-11,638,653,802$ & -21466368517 & $-8,201,268,150$ & 1185432436 & $550,184,283$ \\
\hline more than 5 years & $12,288,183,380$ & 19468184899 & $-4,060,421,398$ & 7329124170 & $13,255,210,991$ \\
\hline Total & $-10,549,052,349$ & -8169149642 & $-5,581,772,976$ & 14151477661 & $15,250,790,794$ \\
\hline Growth Rate & & -22.56034597 & -31.67253361 & -353.5301547 & 7.768186188 \\
\hline
\end{tabular}

Table 4: Aggregated short term and long term net liquidity gap of Rupali BankLtd

\begin{tabular}{|l|l|l|l|}
\hline Year & $\begin{array}{l}\text { Short Term } \\
\text { Liquidity Gap }\end{array}$ & $\begin{array}{l}\text { Long Term } \\
\text { Liquidity Gap }\end{array}$ & $\begin{array}{l}\text { Total Liquidity } \\
\text { Gap }\end{array}$ \\
\hline 2007 & $-11,198,581,927$ & $649,529,578$ & $-10,549,052,349$ \\
\hline 2,008 & -6170966024 & -1998183618 & -8169149642 \\
\hline 2,009 & $6,679,916,572$ & $-12,261,689,548$ & $-5,581,772,976$ \\
\hline 2,010 & $5,636,921,055$ & $8,514,556,606$ & $1,415,147,7661$ \\
\hline 2,011 & $1,445,395,521$ & $13,805,395,274$ & $15,250,790,795$ \\
\hline
\end{tabular}

Analysis of Liquidity Condition of Janata Bank Ltd: The 5 years bucket wise analysis of liquidity shows that Janata Bank usually maintains positive gap in all maturity buckets except " upto 1 month" and "1-3 months" maturity for some initial years of the study. The growth rates are also high throughout the time period of the study concerned.

Table 5: Aggregated short term and long term net liquidity gap of Janata Bank Ltd.

\begin{tabular}{|l|l|l|l|l|l|}
\hline Maturity Bucket & $\mathbf{2 0 0 7}$ & $\mathbf{2 0 0 8}$ & $\mathbf{2 0 0 9}$ & $\mathbf{2 0 1 0}$ & $\mathbf{2 0 1 1}$ \\
\hline & net liquidity gap & net liquidity gap & net liquidity gap & net liquidity gap & net liquidity gap \\
\hline upto 1 month & $-1,170,931,159$ & -1032448028 & $-1,849,716,755$ & $1,439,620,877$ & $3,189,391,806$ \\
\hline 1-3 month & $-1,770,120,530$ & -993263430 & $237,218,158$ & $1,309,058,085$ & $4,595,920,780$ \\
\hline 3-12 months & $1,313,435,161$ & 1960133300 & $3,657,414,318$ & $359,354,778$ & $4,735,897,170$ \\
\hline 1-5 years & $479,133,143$ & $4,459,964,899$ & $3,086,269,694$ & $1,210,3891,116$ & $13,140,406,556$ \\
\hline more than 5 years & $6,798,109,534$ & 4667980832 & $8,729,184,998$ & $5,178,402,126$ & $4,491,298,508$ \\
\hline Total & $5,649,626,149$ & $9,062,367,573$ & $13,860,370,413$ & $20,390,326,982$ & $30,152,914,820$ \\
\hline Growth Rate & & 60.40650008 & 52.94425327 & 47.11242466 & 47.87852518 \\
\hline
\end{tabular}


Table:6 net liquidity gap of Janata Bank Ltd

\begin{tabular}{|c|l|l|l|}
\hline Year & $\begin{array}{c}\text { Short Term } \\
\text { liquidity Gaps }\end{array}$ & $\begin{array}{c}\text { Long term } \\
\text { liquidity gap }\end{array}$ & $\begin{array}{c}\text { Total liquidity } \\
\text { gap }\end{array}$ \\
\hline 2007 & $-1,627,616,528$ & $7,277,242,677$ & $5,649,626,149$ \\
\hline 2,008 & -65578158 & 9127945731 & 9062367573 \\
\hline 2,009 & $2,044,915,721$ & $11,815,454,692$ & $13,860,370,413$ \\
\hline 2,010 & 3108033740 & 17282293242 & 20390326982 \\
\hline 2,011 & $12,521,209,756$ & $17,631,705,064$ & $30,152,914,820$ \\
\hline
\end{tabular}

Analysis of Liquidity Condition of Agrani Bank Ltd:

Although the total liquidity gap of each year is positive and yearly growth rates are also positive but if we observe each bucket separately it reveals negative gap in both short term and long term maturity buckets. This fact is further supported by the aggregated information in table-8.

Table 7:Agrani Bank net liquidity gap

\begin{tabular}{|l|l|l|l|l|l|}
\hline \multicolumn{1}{|c|}{ Maturity Bucket } & \multicolumn{1}{|c|}{$\mathbf{2 0 0 7}$} & \multicolumn{1}{c|}{$\mathbf{2 0 0 8}$} & \multicolumn{1}{c|}{$\mathbf{2 0 0 9}$} & \multicolumn{1}{c|}{$\mathbf{2 0 1 0}$} & \multicolumn{1}{c|}{$\mathbf{2 0 1 1}$} \\
\hline & net liquidity gap & net liquidity gap & net liquidity gap & net liquidity gap & net liquidity gap \\
\hline upto 1 month & $-7,363,692,960$ & -30524141016 & $11,978,012,508$ & 8701342604 & $476,784,683$ \\
\hline 1-3 month & $704,095,350$ & 1016259799 & $10,581,898,138$ & 34054831791 & $31,816,189,959$ \\
\hline 3 -12 months & $10,216,656,438$ & -39033031426 & $25,423,718,438$ & 16841417759 & $23,273,342,911$ \\
\hline 1-5 years & $1,595,158,531$ & 3761131374 & $-17,008,269,976$ & 345410417 & $-59,219,877,384$ \\
\hline more than 5 years & $-1,809,508,076$ & 71198994381 & $-21,808,153,887$ & -44225717803 & $29,596,183,877$ \\
\hline Total & $3,342,709,283$ & 6419213112 & $9,167,205,221$ & 15717284768 & $25,942,624,046$ \\
\hline Growth Rate & & 92.03623673 & 42.80886241 & 71.45121538 & 65.05792463 \\
\hline
\end{tabular}

Table 8:Aggregate short term and long term net liquidity gap of Agrani Bank Ltd

\begin{tabular}{|c|l|l|l|}
\hline Year & $\begin{array}{c}\text { short term } \\
\text { liquidity gap }\end{array}$ & $\begin{array}{c}\text { long term } \\
\text { liquidity gap }\end{array}$ & $\begin{array}{c}\text { total liquidity } \\
\text { gap }\end{array}$ \\
\hline 2,007 & $3,557,058,828$ & $-214,349,545$ & $3,342,709,283$ \\
\hline 2,008 & -68540912643 & 74960125755 & 6419213112 \\
\hline 2,009 & $47,983,629,084$ & $-38,816,423,863$ & $9,167,205,221$ \\
\hline 2,010 & 59597592154 & -43880307386 & 15717284768 \\
\hline 2,011 & $55,566,317,553$ & $-29,623,693,507$ & $25,942,624,046$ \\
\hline
\end{tabular}

\section{Comparative Analysis:}

The comparative analysis of four bank's five year average net liquidity gap shows that on average Sonali Bank faces more negative liquidity gap followed by Rupali Bank and Agrani Bank in short term buckets. In those bucket Janata Bank,s average condition is better than them. However in long term Rupali Bank and Agrani Bank faces adverse condition in 1-5 years group but all the banks are having positive gap in more than 5 years group.

Table $9: 5$ year average net liquidity gap of concerned banks

\begin{tabular}{|l|l|l|l|l|}
\hline \multicolumn{1}{|c|}{ Maturity Bucket } & \multicolumn{1}{c|}{ Sonali Bank Ltd. } & \multicolumn{1}{c|}{ Rupali Bank } & \multicolumn{1}{c|}{ Janata Bank } & \multicolumn{1}{c|}{ Agrani Bank } \\
\hline upto 1 month & $-60,105,964,852$ & 374293281.6 & $115,183,348$ & $-3,346,338,836$ \\
\hline 1-3 month & $-6,561,898,691$ & -2473623861 & $675,762,613$ & $15,634,655,007$ \\
\hline 3-12 months & $-6,048,583,554$ & 1377867619 & $2,405,246,945$ & $7,344,420,824$ \\
\hline 1-5 years & $14,773,438,803$ & -7914134750 & $6,653,933,082$ & $-14,105,289,408$ \\
\hline more than 5 years & $93,643,200,965$ & 9656056408 & $5,972,995,200$ & $6,590,359,698$ \\
\hline Total & 35700192670 & 1020458698 & 15823121187 & $12,117,807,286$ \\
\hline
\end{tabular}

The overall growth rate of total net liquidity gap of all the banks are arranged year wise for four years time period in table 10. According to the information presented all the banks taken under study shows fluctuating but positive growth rate over the time period except Rupali Bank. 
Table 10 : Comparative year wise growth rate of total net liquidity gap

\begin{tabular}{|l|l|l|l|l|}
\hline \multicolumn{1}{|c|}{ Year } & \multicolumn{1}{|c|}{$\begin{array}{c}\text { Growth rate of } \\
\text { Sonali Bank }\end{array}$} & \multicolumn{1}{|c|}{$\begin{array}{c}\text { Growth rate of } \\
\text { Rupali Bank }\end{array}$} & $\begin{array}{c}\text { Growth rate of } \\
\text { Janata Bank }\end{array}$ & \multicolumn{1}{c|}{$\begin{array}{c}\text { Growth rate of } \\
\text { Agrani Bank }\end{array}$} \\
\hline 2008 & 12.30806092 & -22.56034597 & 60.40650008 & 92.03623673 \\
\hline 2009 & 24.80839911 & -31.67253361 & 52.94425327 & 42.80886241 \\
\hline 2010 & 50.19957806 & -353.5301547 & 47.11242466 & 71.45121538 \\
\hline 2011 & 22.542219 & 7.768186188 & 47.87852518 & 65.05792463 \\
\hline Average & 27.46456427 & -99.99871202 & 52.0854258 & 67.83855979 \\
\hline
\end{tabular}

The evaluation of short term liquidity gap of all the banks discloses that Sonali Bank's short term liabilities always exceed short assets giving negative gap for all the years under study and Rupali Bank and Janata Bank had the adverse situation for 2007 and 2009 whereas Agrani
Bank had negative gap in only in the year of 2008. That is in managing short term liquidity Agrani Bank did better consistently and Rupali and Janata showed a recovering tendency after 2008.

Table 11: Comparative short term liquidity gap

\begin{tabular}{|l|l|l|l|l|}
\hline \multicolumn{1}{|c|}{ Year } & \multicolumn{1}{c|}{ Sonali Bank } & \multicolumn{1}{c|}{ Rupali bank } & \multicolumn{1}{c|}{ Janata Bank } & \multicolumn{1}{c|}{ Agrani Bank } \\
\hline 2007 & $-1.02302 \mathrm{E}+11$ & -11198581927 & $-1,627,616,528$ & $3,557,058,828$ \\
\hline 2008 & -61718261597 & -6170966024 & $-65,578,158$ & $-6,854,091,2643$ \\
\hline 2009 & -45941737067 & $667,9916,572$ & $2,044,915,721$ & $47,983,629,084$ \\
\hline 2010 & $-1.11687 \mathrm{E}+11$ & $5,636,921,055$ & $3,108,033,740$ & $59,597,592,154$ \\
\hline 2011 & -41932783418 & $1,445,395,521$ & $12,521,209,756$ & $55,566,317,553$ \\
\hline
\end{tabular}

If we consider the long term net liquidity gap of four banks, Sonali Bank and Janata Bank had long term assets over long term liabilities for all the year from 2007 to 2011 but Rupali Bank and Agrani Bank lacks in assets than liabilities in different years which is really an indication of bad asset liability management and ultimately may end in bankruptcy.

Table12: Comparative long term liquidity gap

\begin{tabular}{|c|l|l|l|l|}
\hline Year & Sonali Bank & \multicolumn{1}{|c|}{ Rupali bank } & \multicolumn{1}{|c|}{ Janata Bank } & \multicolumn{1}{c|}{ Agrani Bank } \\
\hline 2007 & $1.24044 \mathrm{E}+11$ & 649529578 & $7,277,242,677$ & $-214,349,545$ \\
\hline 2008 & 86135975734 & -1998183618 & $9,127,945,731$ & $74,960,125,755$ \\
\hline 2009 & 76417095180 & -12261689548 & $11,815,454,692$ & $-38,816,423,863$ \\
\hline 2010 & $1.57461 \mathrm{E}+11$ & $8,514,556,606$ & $17,282,293,242$ & $-43,880,307,386$ \\
\hline 2011 & 98025086322 & $13,805,395,274$ & $17,631,705,064$ & $-29,623,693,507$ \\
\hline
\end{tabular}

\section{Comparative volatility analysis:}

To measure the volatility in net liquidity gap of five different maturity $\mathrm{CV}$ is calculated for all of the banks and presented in Table:13. From the table 13, it can be observed that "upto 1 month" segment Janata Bank experienced higher volatility in liquidity gap, in "1-3 months" group again Janata had greater variability and in 3-12 maturity Agrani Bank had higher variability.
Whereas in longer term at "1-5 years" group Sonali Bank and at "more than 5 years" bucket Agrani Bank had a very higher $\mathrm{CV}$ than others. However, overall observation indicates that Janata Bank performed well in maintaining consistency in longer term liquidity management.

Table 13: Comparative CV of net liquidity gap

\begin{tabular}{|l|l|l|l|l|}
\hline \multicolumn{1}{|c|}{ Maturity Bucket } & CV of Sonali & CV of Rupali & CV of Janata & CV of Agrani \\
\hline upto 1 month & -0.556846744 & 15.55046893 & 18.43575512 & -5.065591374 \\
\hline 1-3 month & -3.058774546 & -1.997228759 & 3.679419183 & 1.042817885 \\
\hline 3 -12 months & -8.349435868 & 3.363626753 & 0.737185096 & 3.621580759 \\
\hline 1-5 years & 3.379439941 & -1.185434569 & 0.848311026 & -1.881831681 \\
\hline more than 5 years & 0.645111529 & 0.911280769 & 0.299575284 & 6.854595197 \\
\hline & 0.412331089 & 12.36466131 & 0.615386298 & 0.740716423 \\
\hline
\end{tabular}

Analysis of significant difference in net liquidity gap among different banks:

The aforesaid discussion focuses on the differences in net liquidity gap in five time buckets for four $\mathrm{NCB}^{\prime} \mathrm{s}$ in
Bangladesh from several aspects or viewpoint and it has been disclosed that there are differences apparently. Now to know whether there is any statistically significant difference among the mean value of net 
Asian Business Review, Volume 4, Number 2/2014 (Issue 8)

ISSN 2304-2613 (Print); ISSN 2305-8730 (Online)

liquidity gap of concerned banks, "Analysis of Variance" has been performed. The analysis indicates that the mean values of concerned banks are significantly different .

Table 15 shows the result of ANOVA analysis where the test statistic is the $\mathrm{F}$ value which is 6.480483615 and critical value is 3.09839 . Since the test statistic is much larger than critical value, we reject the null hypothesis of equal means and conclude that there is a significant difference among the mean values of net liquidity gap of different banks. And the $\mathrm{p}$ value for $(\mathrm{F}=6.480483615)$ is 0.00305 , so the test statistic is significant at that level.

Table 14: Variance of concerned banks

\begin{tabular}{|l|l|l|l|l|}
\hline \multicolumn{1}{|c|}{ Maturity Bucket } & \multicolumn{1}{c|}{ Sonali Bank } & \multicolumn{1}{c|}{ Rupali Bank } & Janata Bank & \multicolumn{1}{c|}{ Agrani Bank } \\
\hline upto 1 month & $1.12023 \mathrm{E}+21$ & $3.38775 \mathrm{E}+19$ & $4.50922 \mathrm{E}+18$ & $2.87343 \mathrm{E}+20$ \\
\hline 1-3 month & $4.0286 \mathrm{E}+20$ & $2.44075 \mathrm{E}+19$ & $6.18225 \mathrm{E}+18$ & $2.65824 \mathrm{E}+20$ \\
\hline 3 -12 months & $2.55048 \mathrm{E}+21$ & $2.14798 \mathrm{E}+19$ & $3.14393 \mathrm{E}+18$ & $7.07476 \mathrm{E}+20$ \\
\hline 1-5 years & $2.4926 \mathrm{E}+21$ & $3.20182 \mathrm{E}+18$ & $3.18616 \mathrm{E}+19$ & $7.04572 \mathrm{E}+20$ \\
\hline more than 5 years & $3.64941 \mathrm{E}+21$ & $7.74291 \mathrm{E}+19$ & $3.20182 \mathrm{E}+18$ & $2.04071 \mathrm{E}+21$ \\
\hline Total & $2.16687 \mathrm{E}+20$ & $1.59204 \mathrm{E}+20$ & $9.48156 \mathrm{E}+19$ & $8.0566 \mathrm{E}+19$ \\
\hline
\end{tabular}

Table 15: Analysis of Variance

Anova: Single Factor

\begin{tabular}{|c|r|r|c|c|}
\hline Groups & \multicolumn{1}{|c|}{ Count } & \multicolumn{1}{c|}{ Sum } & Average & Variance \\
\hline Column 1 & 6 & $1.04323 \mathrm{E}+22$ & $1.73871 \mathrm{E}+21$ & $1.87233 \mathrm{E}+42$ \\
\hline Column 2 & 6 & $3.196 \mathrm{E}+20$ & $5.32667 \mathrm{E}+19$ & $3.30647 \mathrm{E}+39$ \\
\hline Column 3 & 6 & $1.43714 \mathrm{E}+20$ & $2.39524 \mathrm{E}+19$ & $1.32831 \mathrm{E}+39$ \\
\hline Column 4 & 6 & $4.08649 \mathrm{E}+21$ & $6.81082 \mathrm{E}+20$ & $5.07587 \mathrm{E}+41$ \\
\hline
\end{tabular}

ANOVA

\begin{tabular}{|l|c|r|c|c|c|c|}
\hline Source of Variation & \multicolumn{1}{|c|}{ SS } & \multicolumn{1}{c|}{$d f$} & MS & $F$ & P-value & F crit \\
\hline Between Groups & $1.15898 \mathrm{E}+43$ & 3 & $3.86326 \mathrm{E}+42$ & 6.480483615 & 0.003051 & 3.098391 \\
\hline Within Groups & $1.19228 \mathrm{E}+43$ & 20 & $5.96138 \mathrm{E}+41$ & & & \\
\hline Total & $\mathbf{2 . 3 5 1 2 5 \mathrm { E } + \mathbf { 4 3 }}$ & $\mathbf{2 3}$ & & & & \\
\hline
\end{tabular}

\section{SCOPE FOR FURTHER ANALYSIS}

The concerned study reveals that the mean value of net liquidity gap of four NCB's operating in Bangladesh are statistically significantly different. What we do not know at this point is whether the four means of net liquidity gap are all different or which of the four means is different from the other two, and by how much.

\section{REFERENCES}

[1] Al Shammari, M., and Salimi, M. (1998). Modeling the operating efficiency of banks, A parametric methodology. Journal of Logistic Information Management, Vol. 11.

[2] A, V., \& Ganga. (2009). Bank liquidity Risk Management and Supervision. Journal of Money, investment and banking , 79-126.

[3] Akhter, W., Raza, A., Orangzab, \& Akram, M. (2011). Efficiency and performance of Islamic Banking: The case of Pakistan. Lahore: Far East Research Centre.

[4] Baisi, D. (2005). Corporate Financial Management. Financial Times/Prentice Hall.

[5] Barua, A. (2001). Liquidity Scenario in Commercial Banks of Bangladesh. Journal of business research, 3, 1-16.

[6] Berger, A. N., \& Bouwman, C. H. (2008, October). Financial Crises and Bank Liquidity Creation. Retrieved
March 2010, from Social Science Research Network: http://ssrn.com/abstract $=1231562$

[7] Gatev, E., Schuermann, T., \& Strahan, P. (2007). How Do Banks Manage Liquidity Risks? Evidence from the Equity and Deposit Markets in the Fall of 1998. In M. Carey, \& R. M. Stulz, The Risks of Financial Institutions (pp. 105-132). Chicago: University of Chicago Press.

[8] Vodova, P. (2011). Liquidity of Czech commercial banks and its determinant. International Journal Mathematical Models and Methods in Applied Science.

[9] Shin. H., \& Adam T. (2007). Liquidity and leverage position of commercial banks. Retrieved from http://www.princeton.edu

[10] Mathias, D., \& Nikolaou, K. (2009). Funding liquidity risk definition and measurement. European central bank. Retrieved from http://www.ecb.int/pub/pdf/scpwps/ecbwp1024.pdf

[11] Islam M. Muzahidul \& Chowdhury Hasibul Alam ( 2009), A comparative study of Liquidity management of an Islamic bank and a Conventional Bank: The Evidence from Bangladesh, Journal of Islamic Economics, Banking and Finance, Volume 5, No;1

[12] Jahangir, N., Shill, S., and Haque, M. A. J. (2007). Examination of Profitability in the Context of Bangladesh Banking Industry. ABAC Journal, Vol. 27, No. 2. 